\title{
Implicações entre olhares: etnografia, fotografia e performance $^{1}$
}

\author{
Scott Head
}

Universidade Federal de Santa Catarina, Florianópolis, Brasil

E-mail: head.sc@gmail.com 


\section{Resumo}

Ao apelar para uma figuração 'teatral' da representação imagética, neste ensaio busco ressaltar certos aspectos do olhar fotográfico que o fazem diferir do olhar antropológico encarnado num texto etnográfico. No entanto, em vez de delinear mais uma distinção entre os papéis respectivos da 'imagem' e do 'texto' - uma distinção que já fez gastar muita tinta -, meu apelo a uma perspectiva 'performática' pretende oferecer modos instigantes de driblar as fronteiras impostas por tais classificações. Se tanto imagens fotográficas quanto textos etnográficos podem ser abordados como formas de encenação, não é porque existe pouca diferença entre eles, mas, ao contrário, porque existem tantas diferenças entre formas de imagens quanto entre gêneros de texto. As diferenças em questão, então, só fazem sentido quando postas em jogo em um contexto mútuo: neste caso, o jogo ritualizado e luta dançada conhecido como Capoeira Angola.

Palavras-chave: Performance. Fotografia. Etnografia. Imagem. Texto. Capoeira.
Abstract

Appealing to a 'theatrical' figuration of image-based representation, this essay focuses upon certain aspects of the photographic 'look' that renders it different from the anthropological vision incarnated in an ethnographic text. But rather than offer one more way of distinguishing between the respective roles of 'image' and 'text' - a distinction over which plenty of ink has already been spilled, my appeal to a performance-based perspective aims to offer instigative ways of dribbling the boundaries imposed by such classifications: if both photographic images and ethnographic texts can be approached in terms of the scenarios they enact, it is not because there is little difference between them, but rather because there are as many differences between forms of images as there are between textual genres, such that the differences in question only make sense when placed 'in play' in a shared context: in this case, the ritualized game and danced fighting-form know as Capoeira Angola.

Keywords: Performance. Photography. Ethnography. Image. Text. Capoeira.

ILHA

volume 11 - número 1 
$\mathrm{O}$ presente trabalho se encaixa plenamente no gênero de um "trabalho em andamento". Seu tema se insere no cruzamento teórico entre reflexões e críticas levantadas em relação à representação etnográfica de práticas performáticas e à apresentação performática da própria prática etnográfica e de um papel potencial do olhar fotográfico nessas reflexões. Digo um papel, e não o papel, pois o papel que tenho em mente para tal olhar não é $o$ de oferecer uma contribuição metodológica e, portanto, generalizável para o uso de imagens fotográficas - seja para melhor representar uma ou outra prática performática ou para melhor ilustrar as nossas interpretações dela.

Em vez de seguir fielmente o roteiro do texto que pretende descrever e explicar a prática performática em questão, buscando mostrar exatamente o que o texto diz, vejo um papel menos comportado, mais idiossincrático, para o olhar fotográfico. Imagino o papel desse olhar mais como Brecht vê o ator de seu teatro épico, que, segundo ele, deve não só representar um papel, mas, igualmente, mostrar-se representando o papel, chamando atenção à sua presença subjetiva e corporal no palco como ator, pois, segundo a leitura de Walter Benjamin, um aspecto fundamental dessa "consciência de ser teatro", instigada pelo teatro épico, consiste na sua interrupção da ilusão tão cara ao 'drama naturalista' de 'retratar a realidade' como se a realidade em questão não fosse encenada. De forma parecida, então, aponto para a importância de realizar uma tomada de consciência equivalente de 'ser uma imagem', de tal modo que se interrompa a ilusão de 'retratar a realidade como é', ilusão que passou a fazer parte integral justamente da 'magia' tecnológica da fotografia. 
Através dessa figuração teatral, busco, em primeiro lugar, afirmar a importância de repetir, a respeito da imagem fotográfica, uma tomada de consciência já em andamento - ou pelo menos já afirmada repetidamente - a respeito do texto etnográfico. Nota-se aqui, de passagem, o próprio papel recorrente da metáfora da performance na refiguração da etnografia como uma representação parcial e experimental, e não um retrato fiel da realidade que pretende mostrar. Apontando para alguns exemplos, nos anos 1980, James Clifford começa seu ensaio "Sobre a alegoria etnográfica", que se tornou peça central dos debates sobre a representação, com a afirmação de que, assim como Victor Turner lida com dramas sociais, ele pretende tratar "a própria etnografia como uma performance, com enredo estruturado através de histórias poderosas" (Clifford, 2002, p. 64). Nos anos 1990, Fabian (1990) e Hastrup (1995) também fazem amplo uso dessa concepção da etnografia como performance ou encenação ao reformularem a noção de representação menos como um suposto método científico e mais como um modo conscientemente retórico de reapresentar o encontro etnográfico como uma prática negociada ou práxis. E, na nossa década, Crapanzano (2005) vem elaborando a noção de 'cena' - um conceito explicitamente teatral justamente para dar conta da zona de indiferenciação da vida ainda não 'objetivada' como realidade impessoal ou 'subjetivada' como experiência pessoal, em que imagens e imaginários se confundem com as experiências mais intensas da realidade 'em si'.

A meu ver, tais figurações 'performáticas' da própria prática etnográfica, longe de levar à ficcionalização do real ou à realização de ficções, ajudam a pôr em relevo o ato de conjugar experiências e matérias aparentemente distintas, sem recorrer a julgamentos extrínsecos sobre o fundo 'real' ou 'fantasiado' das experiências ou matérias sendo conjugadas. Mas, voltando à questão da imagem, como aponta Caiuby Novaes (2005, p. 109), as críticas aos modelos clássicos de representação usados na antropologia parecem ainda "não ter sensibilizado os que ainda lidam com a imagem de modo tangencial". Vale lembrar, aqui, que tanto Geertz (1989) quanto Clifford (2002) fazem uso justamente de imagens negativas da fotografia nos seus 
respectivos ensaios tão influentes sobre a poética e a política da representação etnográfica: Geertz apela a tais imagens como exemplo de 'descrições finas', que ele contrapõe a sua reformulação da etnografia como uma 'descrição densa' da cultura; e Clifford começa seu ensaio sobre a 'autoridade etnográfica' apontando para a imagem fotográfica no frontispício da etnografia clássica, Os argonautas do Pacífico Ocidental, como exemplo da afirmação naturalizada da 'presença', que garante a 'autoridade etnográfica moderna'. Em ambos os casos, não se fala mais em fotografia após essa breve aparência, ligeiramente despachada como mero serva do verdadeiro vilão - a vertente naturalista do realismo etnográfico como um modo de escrever.

Daquele momento para cá - e até bem antes, como Marco Antônio Gonçalves (2009) bem demonstra a respeito de Jean Rouch uma boa 'tomada de consciência' antropológica vem sendo elaborada a respeito da imagem, buscando corrigir essa negligência. Mesmo assim, essa tomada de consciência ainda confronta vários obstáculos, dentre os quais destaco dois: primeiro, ela tende a continuar limitada àqueles que tomaram a 'imagem' como seu principal objeto ou instrumento de pesquisa, análise e representação; e, segundo, ela tende a ser mais dirigida a filmes e vídeos etnográficos do que a respeito das imagens fotográficas. Existem, é claro, importantes exceções, tanto no Brasil quanto no exterior, de antropólogos e antropólogas que trabalham com imagens fotográficas, de tal modo que põem em relevo o (pelo menos) duplo papel que vejo como essencial a essa 'tomada de consciência' da imagem.

O que se destaca nesses trabalhos, a despeito de suas diferenças, é um reconhecimento de tais imagens como quase-signos e quase-referentes, quase-'sujeitos' de um discurso em imagens e quase'objetos' em um discurso sobre seus referentes, que tanto se referem ao mundo quanto fazem parte dele, sem serem exatamente uma ou outra coisa; e sem serem exatamente uma 'coisa' ou uma 'ideia', uma forma material ou uma força afetiva. Ou, para apelar ao campo da performance, o que estaria em jogo é o pleno reconhecimento da liminaridade de tais imagens, por habitarem sempre as fronteiras ou frestas entre estados de ser, andando na corda bamba entre a realida- 
de e o imaginário, mesmo se acabam pulando para um lado ou outro de um momento para outro.

Se tanto imagens fotográficas quanto textos etnográficos podem ser abordados como formas performativas, ainda resta a questão das diferenças entre uma e outra forma. Em parte, acho que recorrer ao campo da performance a respeito desse assunto oferece um bom modo de driblar uma distinção que já fez gastar-se muita tinta: a diferença entre imagem e texto. Certamente não quero sugerir que exista pouca diferença, mas, ao contrário, que existem tantas diferenças entre formas de imagens quanto entre gêneros de texto. Mesmo assim, ao apelar a uma crítica teatral e não textual da representação imagética, busco igualmente ressaltar certos aspectos do olhar fotográfico que o fazem diferir do olhar antropológico encarnado num texto etnográfico.

Voltando à questão do teatro épico, Benjamin aponta para dois aspectos extradiscursivos da relação entre a ação sendo representada e o ato de mostrar-se representando: primeiramente, o papel do corpo dos atores e, em particular, de seus gestos ao apresentar o ato de representar; e, segundo, a interrupção da ação como fator crucial na tomada de consciência crítica diante não só da representação teatral em si, mas igualmente do "fluxo real da vida", ou seja, de "condições" da vida social no mundo afora que o teatro épico busca menos 'retratar' do que descobrir e situar. É justamente a esses dois aspectos a presença 'corporal' e a 'interrupção' da ação - que pretendo apelar ao buscar delinear aqui um papel diferenciado para o olhar fotográfico vis-à-vis o texto etnográfico e a teoria antropológica, pois vejo esse olhar como capaz de interromper não só o fluxo de ação que toma como seu foco, mas igualmente o fluir do diálogo sendo encenado entre texto e teoria a respeito da prática performática da qual tratam. E vejo a corporalidade de tal olhar como algo capaz não só de apontar para o não dito do texto e o fora do palco de suas explicações, mas igualmente de estabelecer alianças implícitas com modos discursivos que também resistem ou complicam o avanço do argumento do texto rumo a certa conclusão. 
Reconheço que isso tudo pode não passar de uma mera encenação, no sentido de que, a partir do momento em que interrompem o texto, as próprias imagens fotográficas tornam-se também parte daquilo que interrompem, ou seja, mais uma matéria de interpretação discursiva. Mesmo assim, busco afirmar o valor de ceder um papel relativamente autônomo ao olhar fotográfico, a respeito tanto do olhar interpretativo que roteiriza o texto etnográfico quanto do olhar do leitor que busca o sentido do texto e de suas imagens. Mas antes de abordar algumas imagens tanto produzidas quanto lidas por esse olhar, deixe-me primeiramente adentrar um outro olhar, o 'olhar' da própria prática performática em questão neste trabalho, a capoeira.

A alma da capoeira é o olhar, uma esgrima sutil, ágil; firme, atenta, em que a retina é o florete flexível penetrante indo quase devassar a intenção ainda oculta, o desejo apenas pensado, voltada sempre para o adversário apanhando-lhe todos os movimentos, surpreendendo-lhe os mais insignificantes ameaços, para desviá-los, em tempo, com a destreza defensiva dos braços em rebates lépidos ou evitálos com os desvios laterais e os recuos saltados de corpo, leve, sobre os pés, até facultar e perceber a aberta e entrar, "para ver como é para contar como foi", segundo o calão próprio (Kosmos, 1906).

Essa citação, que retrata o olhar da capoeira como a própria alma dessa prática, faz parte de um artigo publicado na revista literária Kosmos, no Rio de Janeiro, em 1906, mais de uma década depois de a presença pública dos capoeiristas - antigos protagonistas dessa luta dramática assim como de outras 'desordens' - ter sido forçosamente erradicada das ruas da então capital do país.

Apesar de essa descrição da 'alma' da capoeira ser duplamente deslocada no 'então' do passado, tanto para nós quanto para o próprio autor, peço licença para nos determos no olhar que ela evoca, pois vejo naquele olhar algo estranhamente familiar.

Ao evocar a maneira como o capoeira buscava "facultar e perceber" as intenções de seu adversário com tal olhar, não somente para se defender de potenciais ataques, mas igualmente para penetrar as defesas do outro, esse trecho põe em questão qualquer distinção 
nítida entre pensamento, percepção e ação na luta de que se trata. Ou seja, todos os três são colocados como se no mesmo plano de movimento, plenamente envolvidos no seu desdobrar. Ao mesmo tempo, a descrição aponta para o processo dramático de revelação e ocultação encenado entre esses olhares. Desse modo, ela desloca o foco de sentido dessa prática a um plano não plenamente visível 'em si', ou seja, por um observador distanciado do seu desdobrar naquele plano. A citação incorpora a percepção no plano de ação dessa luta, de tal modo que seu 'dentro' e 'fora' se confundem, ao mesmo tempo que ambos se fundem em torno do mesmo objetivo e tropo de penetração - tanto das intenções quanto das defesas do adversário. Portanto, a descrição também desloca essa adversidade constitutiva da ação para o próprio plano de percepção. Ou seja, a percepção do jogo fica cindida entre os dois olhares, um se contrapondo ao outro, implicandose reciprocamente, sem a distância comumente atribuída à visão.

Se a 'alma' da capoeira consiste no seu olhar e esse olhar, tal como descrito, é nada senão implicante diante do seu adversário, fica evidente, mesmo nesse pequeno trecho, que tal olhar também implicou o ponto de vista de seu autor ao fazê-lo buscar evocar, ou até invocar, a sua 'alma' mais de 15 anos depois da chamada 'morte' da capoeira no Rio de Janeiro - certo homicídio sociocultural perpetrado pelo governo republicano assim que chegou ao poder, através de uma longa e violenta campanha de repressão policial. Não sabemos até que ponto o autor desse artigo - assinado por L.C., ou César Câmara de Lima Campo, um poeta simbolista - era pessoalmente familiarizado com a arte de capoeiragem. Porém, fica evidente que essa 'alma' permaneceria nada mais que um mero fantasma para quem ficasse observando apenas de fora, sem ter participado, de algum modo, no imaginário de sua ação e na percepção de seu imaginário. Desse modo, podemos testemunhar a sua agilidade em conjugar palavras ao fazê-las dançar de tal modo que ressoam com a dança dos corpos e olhares aos quais se referem e cuja 'alma' se manifesta como se na dobra profana entre a luta dançada e o seu descrever.

Mas, passando à última frase do trecho citado, "ver como é para contar como foi", o que me instiga nessa frase é como figura um 
eventual golpe de capoeira como se fosse um ato de 'investigação', implicando certa continuidade entre o ato de ver e sua expressão ulterior. Tomando o lugar do ato ao qual alude, essa frase evoca igualmente o deslize entre a narração do evento e o evento narrado, como se o desejo de contar precedesse (ou até 'justificasse') o ato que passará a ser contado. E, já que estou tomando liberdades com a interpretação dessa frase, deixe-me estendê-la mais ainda ao deslocá-la daquele jogo de olhares 'ali' naquele texto e no 'então' do passado rumo ao 'aqui e agora' desta comunicação.

Assim relocalizada, "ver como é para contar como foi" sugere um modo singular de figurar a relação entre o olhar etnográfico no campo e o contar, ou 'dar a ver', desse olhar no texto etnográfico, pois, longe de sugerir uma observação distanciada, o ato de 'ver' consiste numa aproximação repentina que resulta num golpe que não só interrompe o jogo entre olhares, mas permite contar o ato de interrupção posteriormente. Ou seja, poderíamos ler essa refiguração do olhar num ato brusco de penetração como uma alegoria da transformação do olhar etnográfico 'classicamente moderno' observacional, distanciado - num olhar mais propriamente fotográfico - um olhar que não só participa da ação mas interrompe-a com os seus cortes e que, através desses cortes, produz lembranças daquela ação na forma de imagens.

Vale apontar aqui que essa figuração do olhar etnográfico como um modo de ver que resulta em golpes implica certa violência a tal olhar. Porém, podemos igualmente inverter o tropo de 'penetração' que caracteriza essa substituição, apelando ao impacto que as imagens produzidas por tais golpes são capazes de exercer na própria representação etnográfica e interpretação antropológica, modificando a sua perspectiva, pois tal figuração do olhar fotográfico difere radicalmente daquelas de Geertz e Clifford antes mencionadas, em que a fotografia é tratada como tropo naturalizado da distância e da pretensa neutralidade do olhar etnográfico 'classicamente moderno'. Em vez de distância, o olhar fotográfico assim refigurado põe a ênfase justamente na proximidade ou no estranhamento daquele olhar com o referente das imagens que produz. 
Segundo Caiuby Novaes (2009, p. 55), seria justamente essa "impressão de proximidade com o que ela representa" que fez com que muitos cientistas sociais, e antropólogos particularmente, se afastassem da imagem, optando por adotar "uma posição de estranhamento e distância com relação àquilo que querem analisar". Mas assim como existem proximidades tanto empáticas quanto potencialmente violentas, e proximidades tanto naturalizadas quanto conscientemente figurativas, acho importante salientar que também existem diferentes formas de estranhamento que não devemos confundir - ou pelo menos não sem propósito. Desse modo, mesmo uma imagem bem 'realista' é capaz de realizar um 'efeito de estranhamento' - conceito dramatúrgico de Brecht - em relação ao texto etnográfico igualmente realista em que é inserida, interrompendo a própria interpretação textual sendo oferecida. A meu ver, a tomada de consciência de 'ser uma imagem', assim como aquela de 'ser um texto', envolve menos a busca de uma distância ou proximidade mais 'certa' do que um descentramento da perspectiva tanto 'natural' quanto 'científica', pois tal descentramento de um modo 'certo' de ver permite uma aproximação experimental com o certo modo de ver da prática ou das pessoas com que lida.

Passando ao presente da prática performática em questão, adianto que todas as imagens das quais farei uso foram tiradas por mim, nos últimos 15 anos, inicialmente muito mais em função do meu papel como praticante dessa luta dançada e jogo ritualizado conhecido como Capoeira Angola do que em função do meu papel como pesquisador desse estilo de capoeira no Rio de Janeiro.

Basta olhar para uma típica revista de capoeira para acharmos o que talvez sejam suas duas faces predominantes, pelo menos tais como disseminadas pela mídia. Na capa da frente, é provável acharmos a fotografia de uma sedutora jovem (tipicamente, branca e loura) executando um movimento de capoeira ou tocando o berimbau. Aqui, capoeira consiste numa bela dança comemorando a sensualidade livre da cultura brasileira.

Se virarmos para a contracapa, a outra face da capoeira estará provavelmente presente, frequentemente em anúncios de produtos 
esportivos, representando homens jovens com tatuagens e músculos protuberantes, pele amorenada e rostos carrancudos. Nessa versão da capoeira, os corpos normalmente ameaçadores dos "marginais" são contidos pela presença da marca registrada na forma inócua de uma mera comodidade, ao mesmo tempo que aqueles corpos dão forma a sonhos belicosos de um poder incontido.

Precisamos apenas abrir uma dessas revistas para acharmos a versão popularizada da história da capoeira correspondente a cada uma dessas imagens. Em um caso, a bela dança será provavelmente contrastada com a associação passada da capoeira com as gangues ou maltas de capoeiras e suas navalhas tão ameaçadoras. No outro, o espetáculo moderno de força física, velocidade e bravura masculino será diferenciado do que um dia fora uma brincadeira inofensiva, jogada por escravos e seus descendentes em suas horas "livres". Apesar de aparentemente opostas, essas duas versões refletem-se uma na outra, como imagens inversas da "mesma" história: no final, é de pouca importância se a capoeira é uma dança mascarada como luta, ou uma luta mascarada como dança, desde que seu movimento do passado para o presente seja moldado através da narrativa da história como progresso.

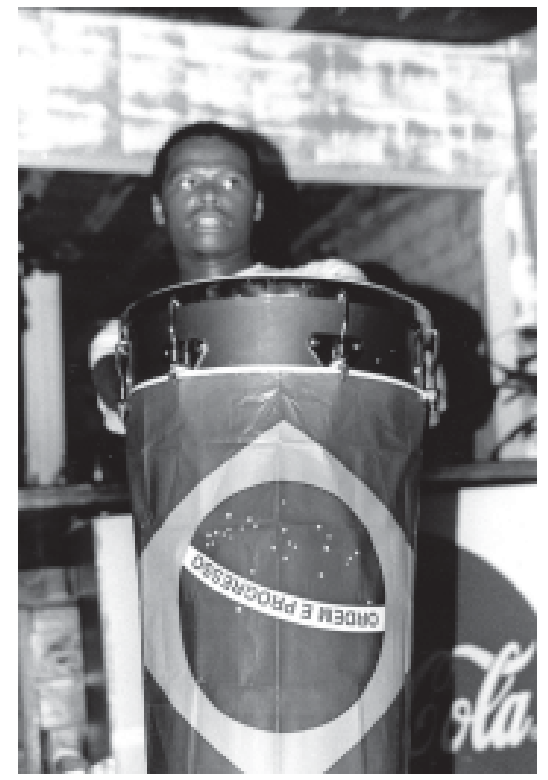

Figura 1

ILHA

volume 11 - número 1 
Mas assim como os capoeiristas costumam inverter seus corpos naquela luta dançada e jogo ritualizado, podemos igualmente inverter os nossos olhares sobre a história em questão. Quando, em 1889, Sampaio Ferraz, o recentemente escolhido Chefe de Polícia, apresentou-se ao marechal transformado em presidente, Deodoro da Fonseca, suas primeiras palavras, segundo dizem, foram: "Aqui estou, Marechal, a seu serviço e à República, para arrancar da nossa terra a maior vergonha: o capoeira!" (Ferraz, 1952, p. 36 apud Dias, 2001, p. 127). Logo a seguir, todos os suspeitos de serem capoeiras foram recolhidos e sumariamente - sem audiência ou julgamento deportados, em muitos casos para a colônia penal de Fernando de Noronha.

E, como se sabe, essa 'limpeza' das ruas da presença dos capoeiras foi apenas o primeiro passo para retalhar a paisagem da cidade da então capital do país. Não muito tempo depois de tomar o poder, a administração republicana iniciou uma massiva campanha de transformação urbana, agora com o propósito de eliminar os cortiços, ou Cabeça de Porcos, assim como de remover os habitantes das classes baixas tanto 'vadios' quanto vendedores ambulantes, e predominantemente negros, do centro da cidade. Como Sidney Chalhoub (1990, p. 186) coloca,

Ao perseguir capoeiras, demolir cortiços, modificar traçados urbanos - em suma, ao procurar mudar o sentido do desenvolvimento da cidade - os republicanos atacavam na verdade a memória histórica da busca da liberdade. Eles não simplesmente demoliam casas e removiam entulhos, mas procuravam também desmontar cenários, esvaziar significados penosamente construídos na longa luta da cidade negra contra a escravidão.

ILHA

volume 11 - número 1 


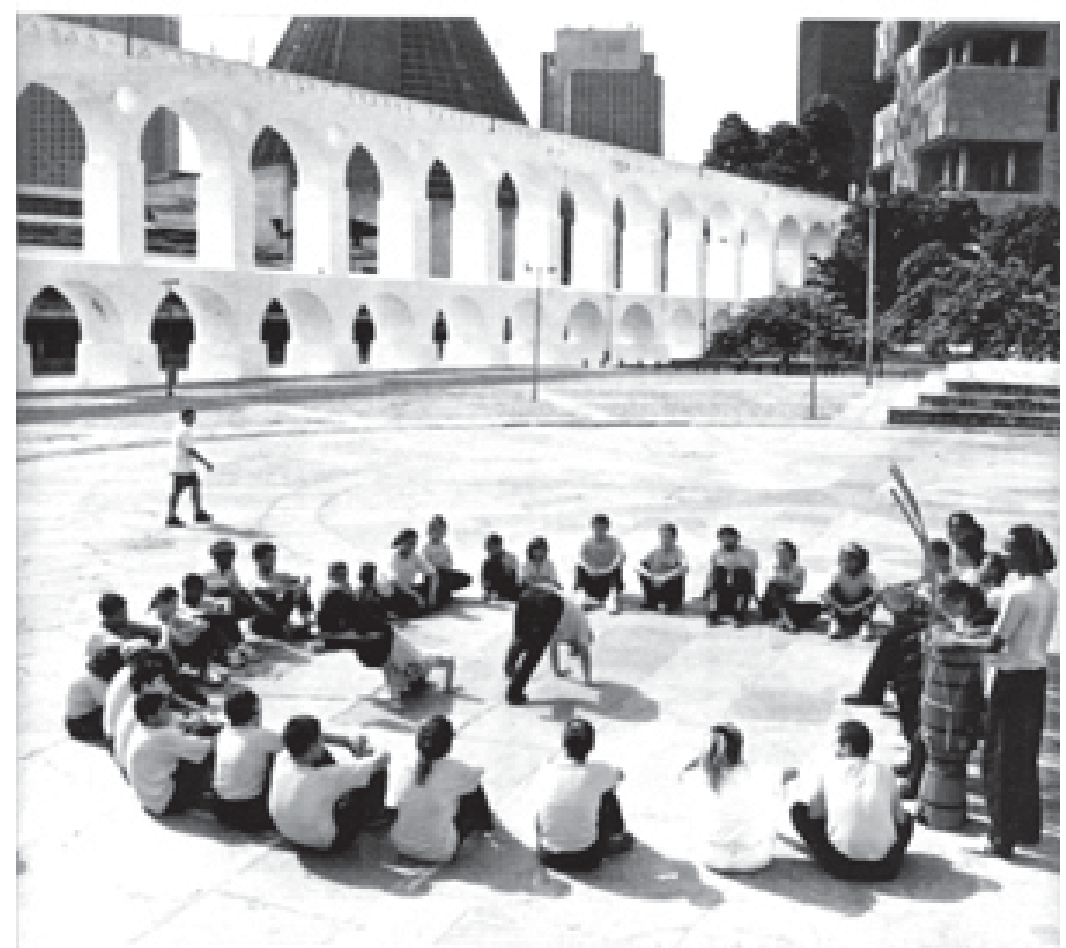

Figura 2

Por um ângulo, o amplo espaço vazio ao redor dessa roda sob os Arcos da Lapa parece confirmar o sucesso da operação de "limpeza" de tais espaços dos 'elementos' indesejados e dos 'amontoados' urbanos. Do mesmo modo, o jogo em si parece com tudo menos com uma ameaça ao mundo ao redor. 


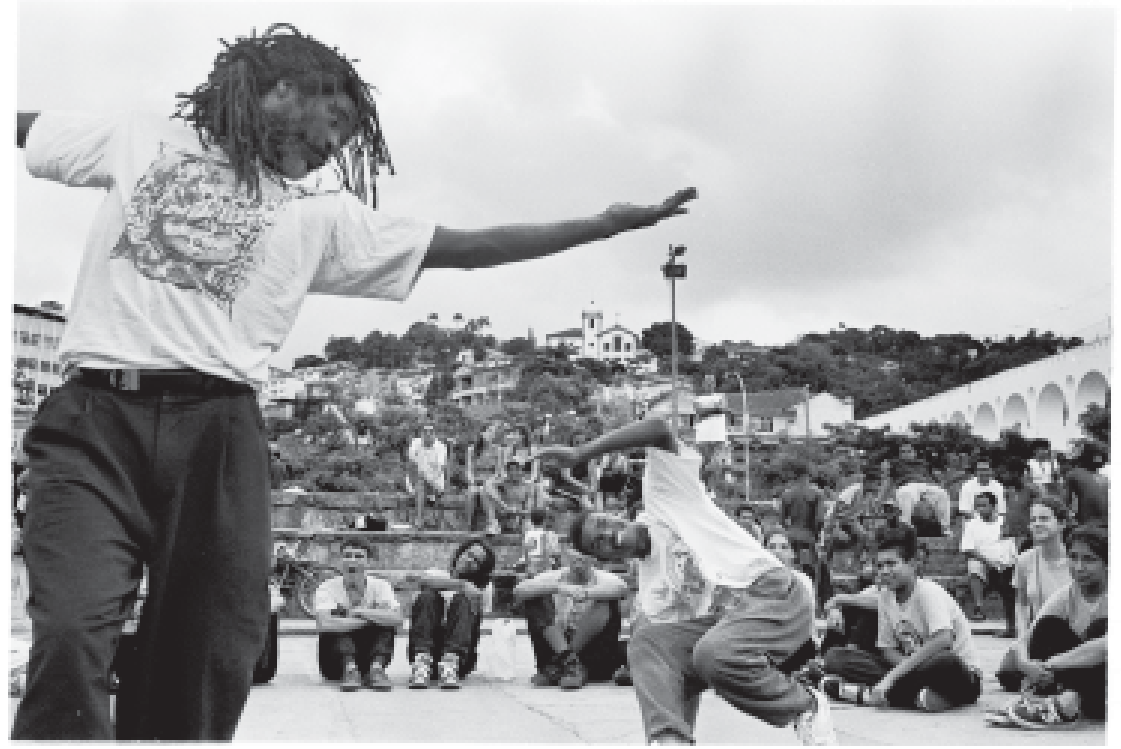

Figura 3

Ainda assim, muito do espírito dos capoeiras sobreviveu nesse bairro, tanto literal como metaforicamente, em malandros verdadeiros como Madame Satã e em verdadeiros espíritos como 'seu' Zé Pilintra.

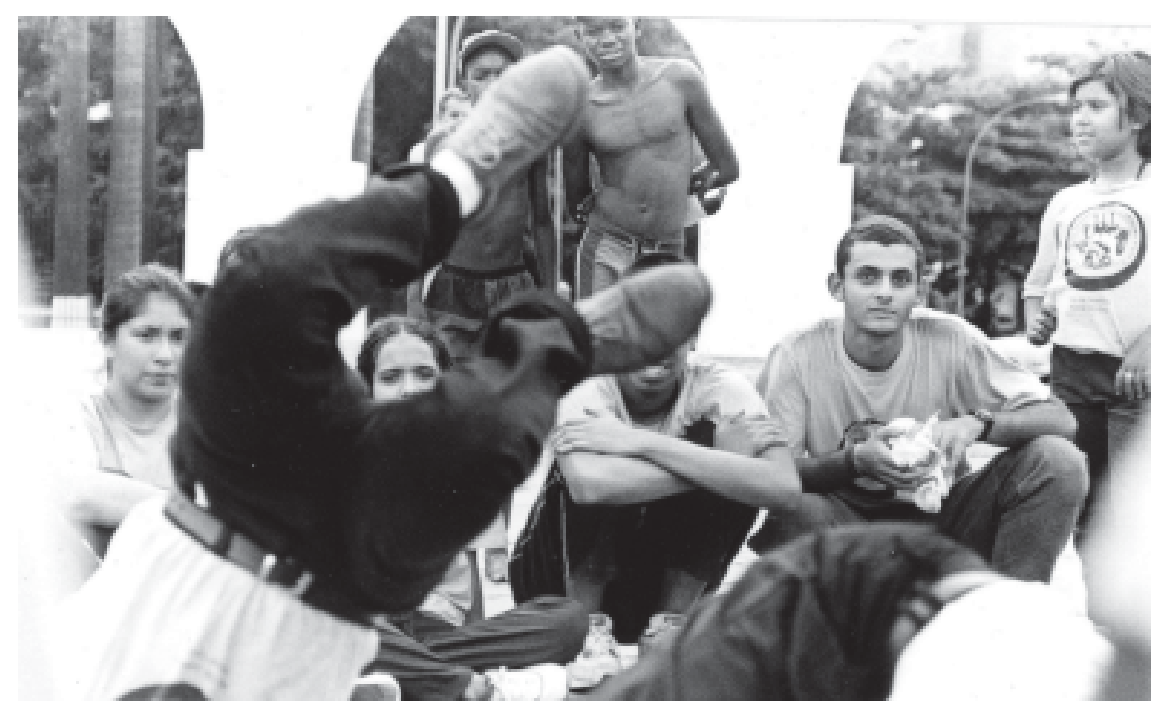

Figura 4

ILHA 
Além do mais, quando rodas localizadas mais ou menos no mesmo lugar são vistas sob diferentes ângulos, o velho aqueduto, o convento e outros traços do Rio antigo, assim como o olhar curioso da audiência, atestam a contínua complexidade e persistente vitalidade tanto da arte quanto de seu vínculo renovado com o espaço urbano ao redor e algo da história que ainda tanto povoa quanto assombra aquele mundo.

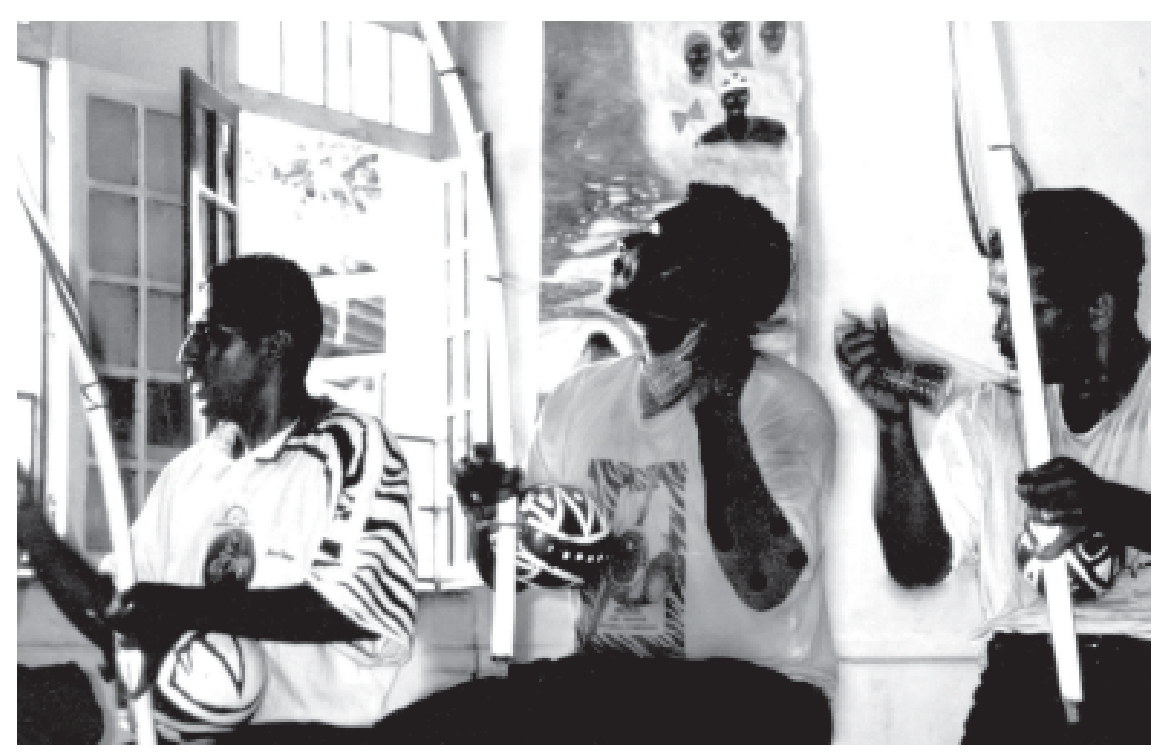

Figura 5

Tanto nas canções, ou corridos, que acompanham o jogo de Capoeira Angola quanto nas filosofias pregadas pelos mestres aparecem referências constantes ao 'jogo de dentro' e ao 'mundo afora', e às conexões variadas entre um e outro. 


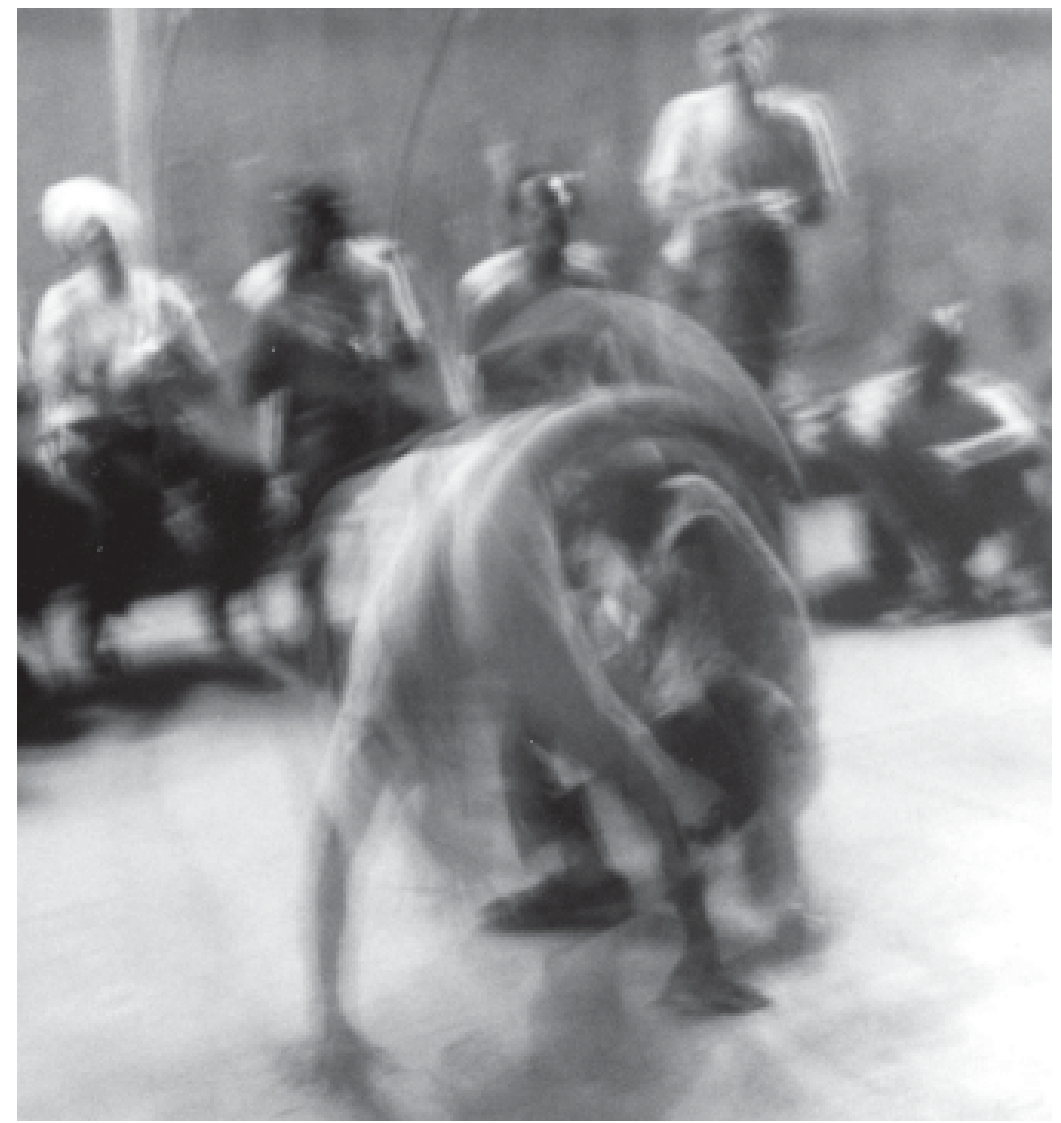

Figura 6

A expressão 'jogo de dentro' não designa um aspecto do jogo facilmente observável ou claramente delineado, mas sim uma qualidade de experiência ambiguamente definida mas profundamente sentida que emerge da constante troca de movimentos ofensivos e defensivos entre os jogadores, sem, no entanto, ser limitada por eles. 


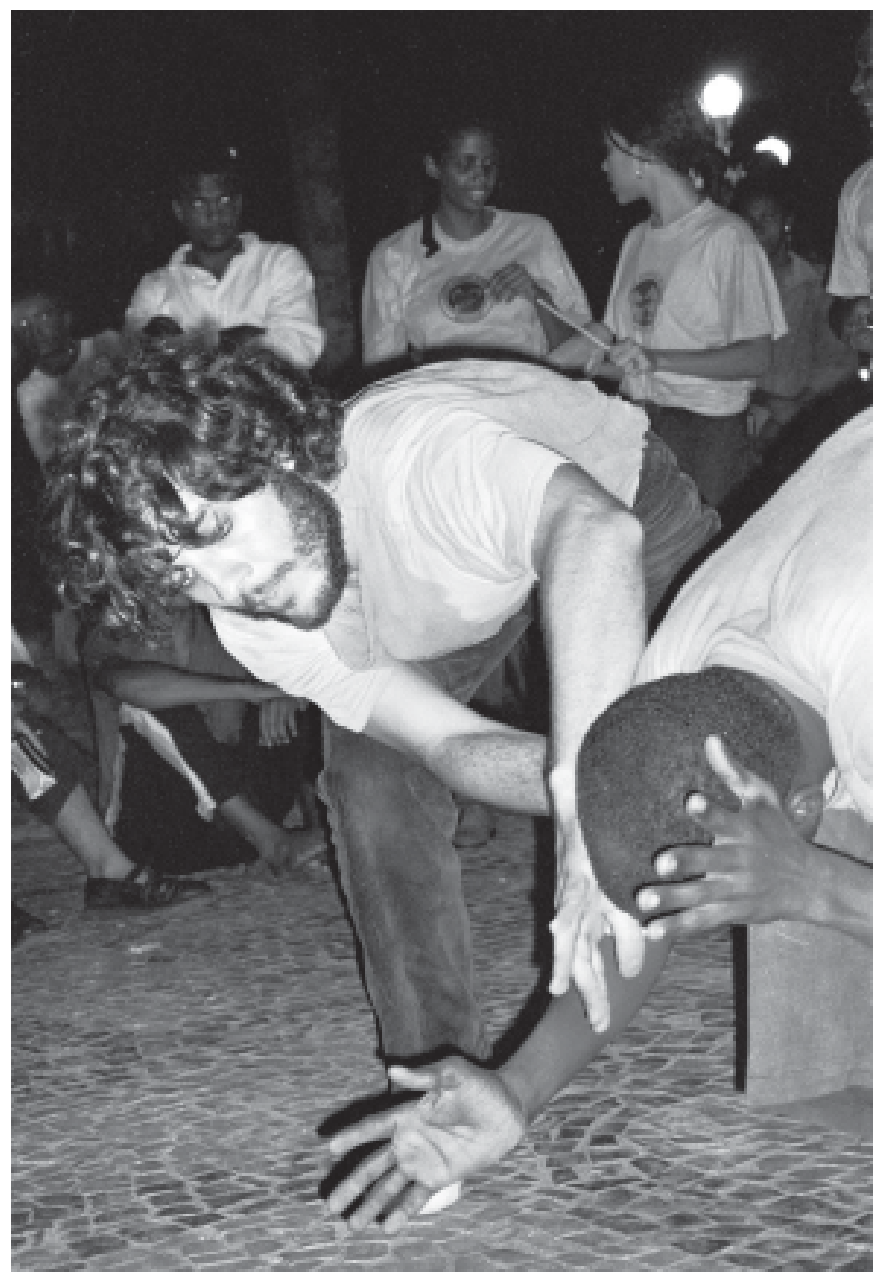

Figura 7

O 'jogo de dentro' está dobrado ou revelado nessa arte, menos no interior dos corpos ou mentes de seus praticantes e mais no meio desses corpos pensantes enquanto dançam e constantemente se desafiam a descobrir um modo de 'sair' de um golpe possível ou de achar uma 'entrada' nas defesas do outro, "para ver como é para contar como foi". 


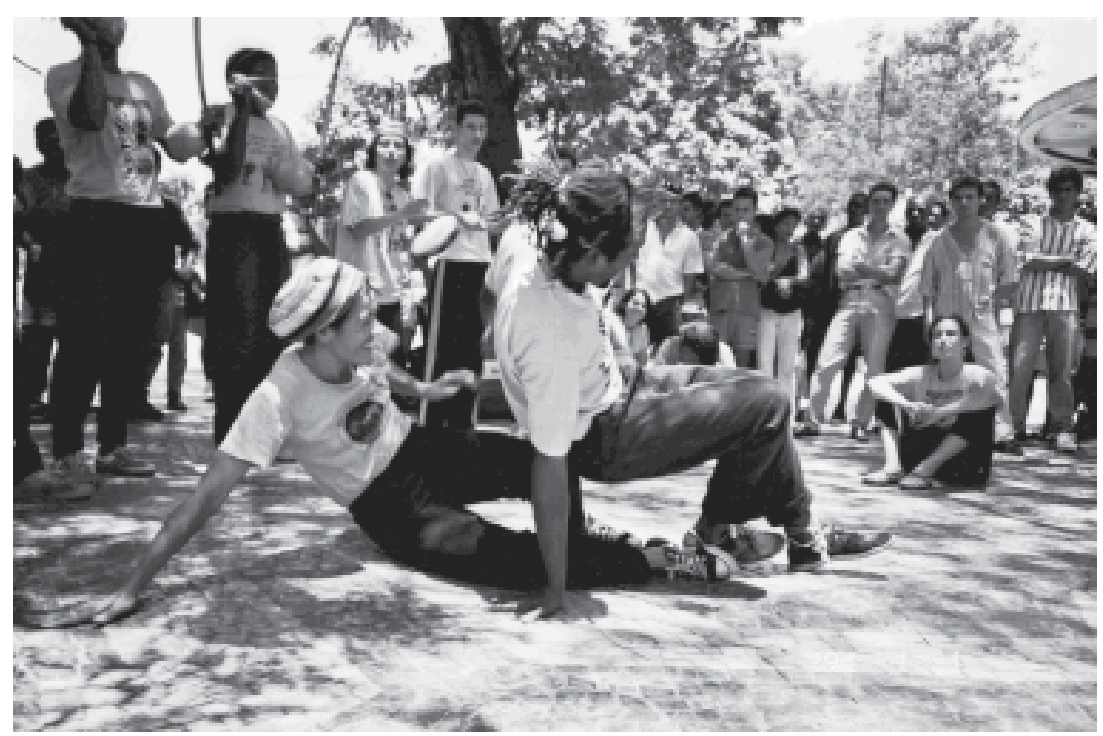

Figura 8

Se esse aspecto do jogo se desdobra num plano que não é fechado em si - como uma interioridade subjetiva separada da objetividade das coisas e dos corpos -, ele também não se desdobra unicamente no plano do visível.

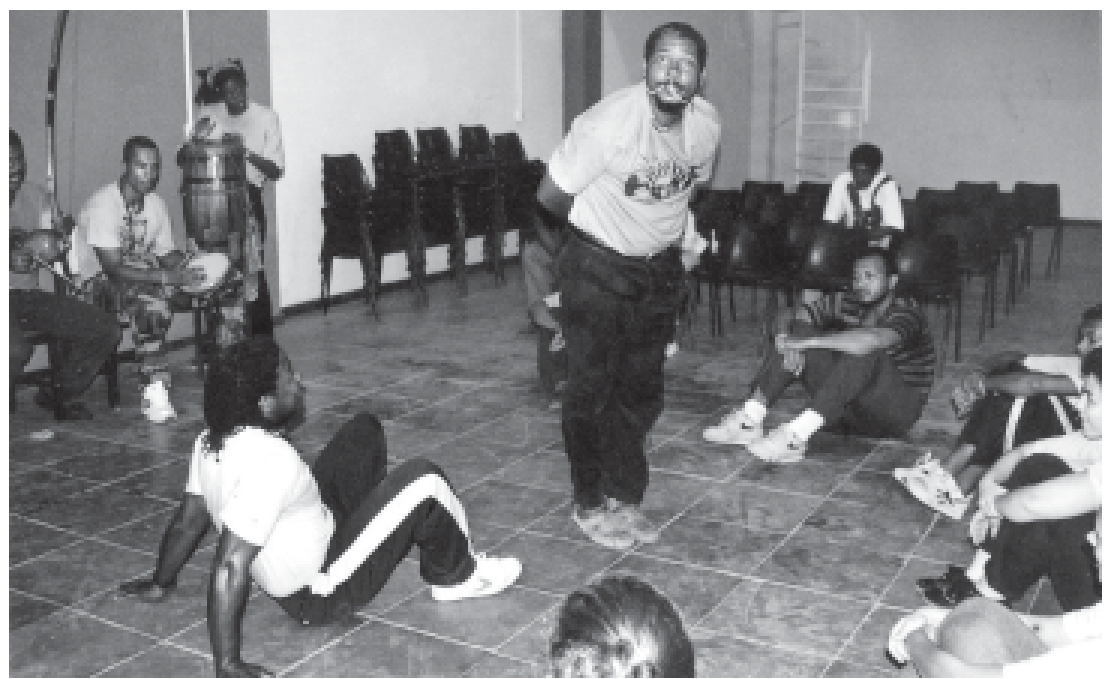

Figura 9 
Ao mesmo tempo, esse jogo é capaz de dobrar não só o plano do visível mas até o próprio ato fotográfico no seu próprio plano de movimento, como no caso da Figura 9, pois aqui o capoeirista que finge estar posando para minha foto faz uso dessa distração encenada que o deixa aparentemente vulnerável justamente para enganar seu adversário, convertendo o jogo a seu favor.

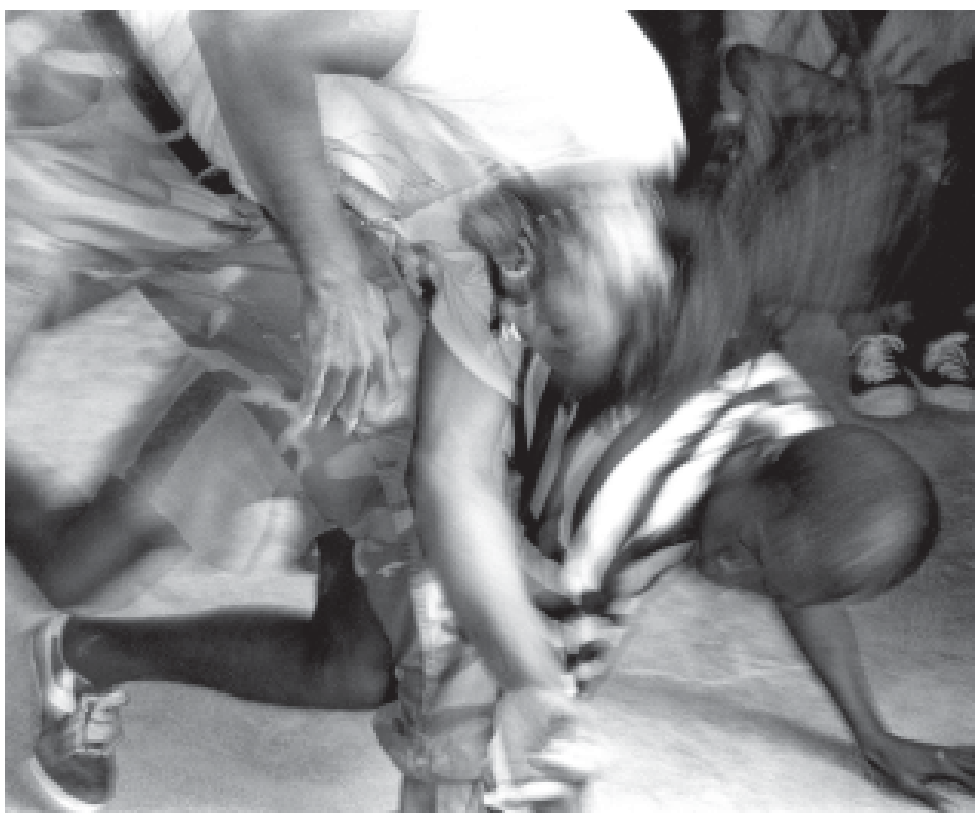

Figura 10

Dado que tanto desse jogo se desdobra além do plano do imediatamente visível, o jogo de dentro certamente apresenta um desafio ao olhar fotográfico, que no máximo pode evocar aspectos de seu desdobrar, mas nunca captar o desdobramento do jogo em si. Mesmo assim, sugiro que, para evocar o desdobrar desse jogo como algo não plenamente visivel, a fotografia tem certa vantagem paradoxal sobre outras tecnologias visuais como o filme e o vídeo, pelo menos quando estes últimos são tratados como registros visuais que captam a realidade do movimento, e não montagens experimentais de uma nova realidade, pois, ao cortar ou interromper o movimento em vez de captá-lo, a fotografia permite não só criar a impressão da realidade-em-movimento, mas igualmente a expressão de afetos apenas vislumbrados. 


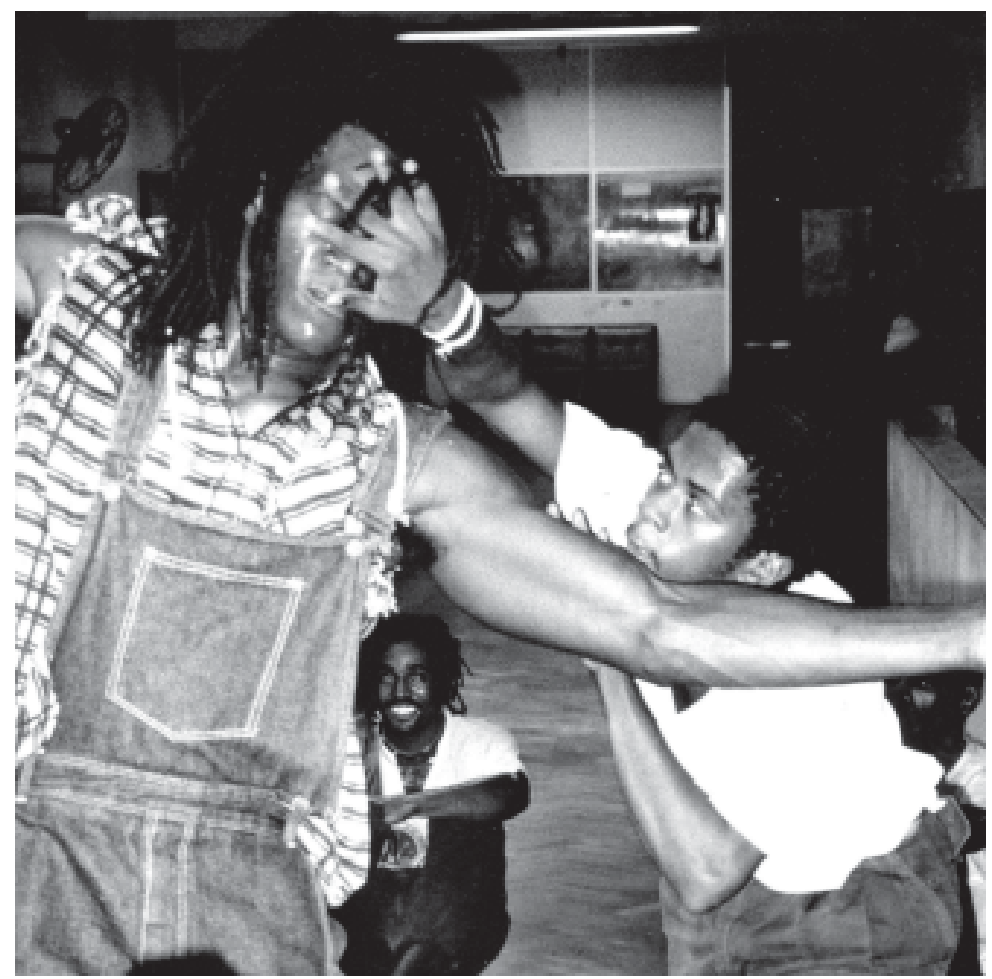

Figura 11

Aqui é em parte essa própria estranheza implícita no uso de imagens fotográficas, ao retratar uma prática 'em movimento' e o movimento da cultura ao seu redor, que instiga o seu uso, ou seja, o que se busca aqui nessas imagens é menos seu 'efeito de realidade' e mais seu efeito de estranhamento em relação ao movimento que retratam e as relações móveis e singulares que tal estranhamento permite ressaltar. Victor Turner, ao tratar de práticas performáticas como 'espelhos mágicos' que não só refletem mas refratam o mundo ao redor, oferece igualmente certo 'espelho mágico' a essa estranha liminaridade da imagem. Como aponta John Dawsey (2009), a subjuntividade característica de tais estados liminares é capaz de abrir "fendas no real, revelando o seu inacabamento". 


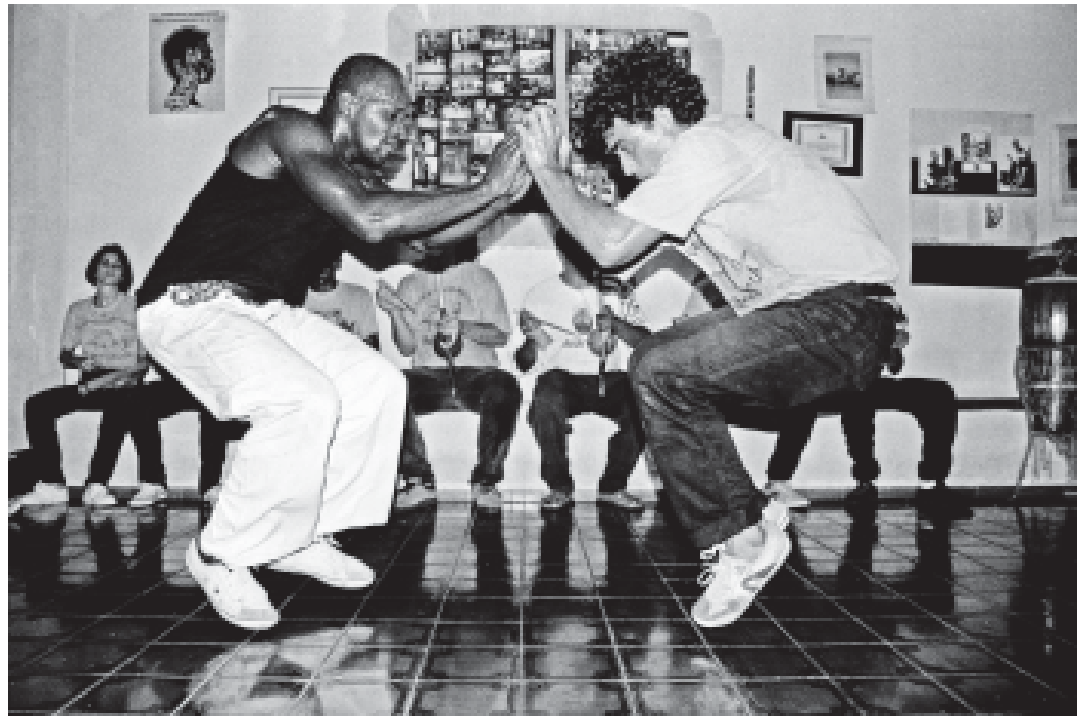

Figura 12

Se imagens fotográficas espelham o mundo, existe uma falha em tal espelho, pois - a não ser no sentido lacaniano - o espelho não fixa aquilo que espelha. Mas de forma parecida com tais estados liminares, essa 'falha' da fotografia pode também fazer com que ela sirva mais como um 'espelho mágico'. E, se for o caso, essa magia da fotografia pode se prestar a evocar algo da mandinga dessa luta dançada e jogo ritualizado, como visto pelo olhar de seus praticantes e pelo jogo de espelhamento um tanto traiçoeiro que esses praticantes realizam entre si. 


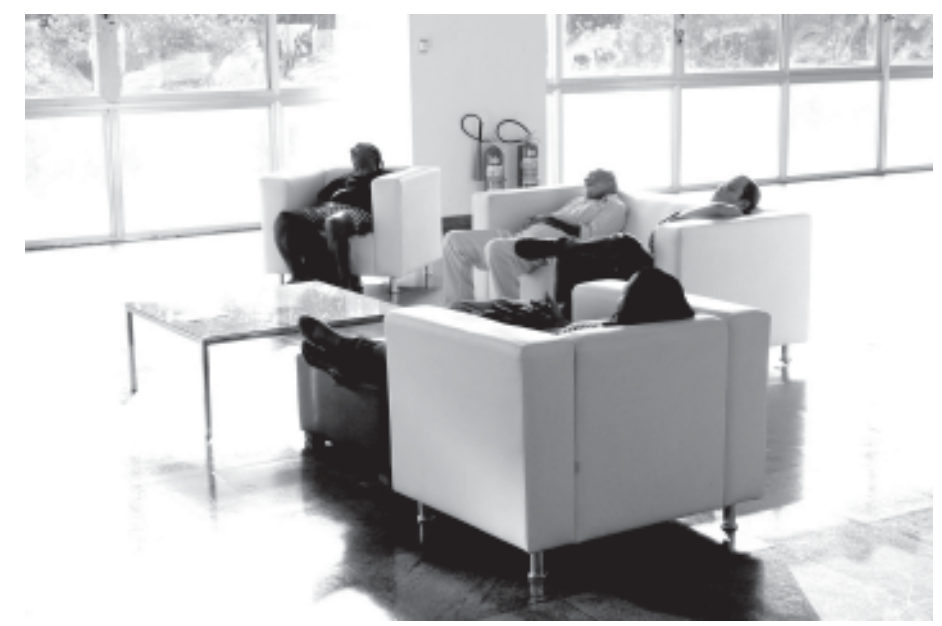

Figura 13

Termino aqui com uma imagem teórica 'em grande angular' não mais direcionada à capoeira, mas à relação mais geral entre práticas performáticas e o próprio ato fotográfico e o imaginário que ambos põem em evidência. Apresento essa 'imagem' teórica mais como uma hipótese que venho elaborando de variados ângulos do que como uma conclusão a respeito da matéria apresentada.

Ao abordar tanto a invenção contínua quanto a violência velada da cultura através do 'prisma' de práticas performáticas, a antropologia encontra um potente 'aliado' no desafio de ressaltar e adentrar os papéis ativos do corpo e da imaginação em tais processos, sem reduzir o movimento da cultura a um mero fluxo de signos desenraizados de qualquer suporte material, experiência vivida ou processo imaginativo. Práticas performáticas assumem um papel exemplar, neste caso, ao porem o movimento da cultura em relevo, justamente como um fluir de formas e forças, de signos e afetos, um se dobrando no outro - um fruir contínuo de sentido através da articulação cinética e sinestésica dos sentidos. Ao mesmo tempo, elas deslocam e enquadram o movimento em questão, efetuando uma descontinuidade entre a prática e o mundo ao redor; elas subtraem tal realidade-em-movimento de suas coordenadas 'ordinárias' e impõem outras coordenadas - desta vez 'extraordinárias' - às condições de sua percepção e 
compreensão. Ou seja, práticas performáticas tanto se entranham no movimento da cultura quanto se estranham dele.

Mas aqui pergunto se esta última frase não poderia igualmente ser relida a respeito do ato fotográfico em si: que as imagens assim tiradas "subtraem tal realidade-em-movimento de suas coordenadas 'ordinárias' e impõem outras coordenadas - desta vez 'extraordinárias' - às condições de sua percepção e compreensão". Ou seja, figurado dessa forma, o ato de tirar uma fotografia seria capaz de cristalizar, como se num só gesto mágico, parte do processo através do qual tais práticas performativas não só apresentam o movimento da cultura no mundo ao redor, mas transformam o movimento assim apresentado, emprestando-lhe o ar de algo 'extraordinário', mesmo se apenas por um momento.

Reconheço que essa simetria formal logo se desfaz diante das diferenças que aparecem quando se põem essas práticas nos seus respectivos campos de ação e significação. Aqui, o papel do olhar etnográfico e antropológico nessa equação consistiria justamente em desconstruir tal simetria formal e reconstruí-la a respeito das temporalidades distintas das práticas em questão e dos olhares singulares que ambos envolvem. Mas, a meu ver, isso poderia transformar a própria etnografia num escrever mais propriamente imagético que se desloca entre a interpretação de signos e a evocação de afetos, e entre a análise de seu 'objeto' e a imersão no seu 'sujeito', ou seja, desdobrar o movimento da cultura como um fluxo de formas e forças, corpos e signos, discursos e imagens que se diferenciam mesmo quando se repetem e que se deslocam mesmo quando buscam fixar.

Mas, para finalizar, eu peço a vocês que olhem mais atentamente essa Figura 13 ou, se preferir, que fechem os seus olhos. Ao elaborar a potencial contribuição da fotografia à etnografia da performance, busco apontar para a sua estranha capacidade, como uma imagem fixa, não de representar o movimento da realidade ou a realidade do movimento, mas de indicar, conjugar ou até 'conjurar' um outro plano de movimento de sentido. Esse plano consistiria não no movimento dos seres, mas nas relações entre os seres - e não nas 
relações cognitivas ou 'estruturais' com que poderíamos fixar essas relações, mas nas relações perceptivas, afetivas e até imaginárias ou sonhadas que tanto animam quanto assombram o mundo vivido e desestruturam, deslocam e transformam nossos saberes. Se fosse colocar uma legenda nessa foto, ficaria dividido entre duas. O olhar antropológico já sugere: 'Sonhos interruptos que continuam'. Mas do ponto de vista 'nativo' em questão, poderia ser, quem sabe: 'As ondas do mar'.

\section{Nota}

1 Agradeço aos mestres Angolinha, Braga, Cobra Mansa, Jurandi, King, Manoel, Neco e Urubu, assim como aos muitos capoeiristas que fotografei ao longo dos anos, especialmente Marcelo, Sônia Maria e Renato, por terem compartilhado essas imagens das muitas performances da capoeira. Todas as fotos são do autor.

\section{Referências}

CAIUBY NOVAES, Sílvia. O uso da imagem na Antropologia. In: SAMAIN, Etienne (Org.). O fotográfico. São Paulo: Hucitec/Senac, 2005. p. 107-113.

. Imagem e ciências sociais: trajetória de uma relação difícil. In:

BARBOSA, Andréa; CUNHA, Edgar Teodoro da; HIKIJI, Rose Satiko (Org.). Imagem-conhecimento: antropologia, cinema e outros diálogos. Campinas, SP: Papirus, 2009. p. 35-60.

CHALHOUB, Sidney. Visões da liberdade: uma história das últimas décadas da escravidão na corte. São Paulo: Companhia das Letras, 1990.

CLIFFORD, James. Sobre a alegoria etnográfica. In: GONÇALVES, José Reginaldo Santos (Org.). A experiência etnográfica: antropologia e literatura no século XX. Rio de Janeiro: Ed. UFRJ, 2002. p. 63-100.

CRAPANZANO, Vincent. A cena: lançando sombra sobre o real. Mana, v. 11, n. 2, p. 357-383, 2005.

DAWSEY, John. Por uma antropologia benjaminiana: repensando paradigmas do teatro dramático. In: CARDOSO, Vânia Z. Anais do Colóquio Antropologias em Performance. Florianópolis: Nuppe/UFSC, 2009. p. 160-194.

DIAS, Luiz Sérgio. Quem tem medo da capoeira? Rio de Janeiro, 1890-1904. Rio de Janeiro: Arquivo Geral, 2001. 
FABIAN, Johannes. Power and Performance: Ethnographical Explorations through Proverbial Wisdom and Theater in Shaba, Zaire. Madison: University of Wisconsin University Press, 1990.

GEERTZ, Clifford. Uma descrição densa: por uma teoria interpretativa da cultura. In: Koogan, 1989. p. 13-44. . A interpretação das culturas. Rio de Janeiro: Guanabara

GONÇALVES, Marco Antônio. Encontros 'encorporados' e conhecimento pelo corpo: filme e etnografia em Jean Rouch. In: CARDOSO, Vânia Z. Anais do Colóquio Antropologias em Performance. Florianópolis: Nuppe/UFSC, 2009. p. $92-$ 110.

HASTRUP, Kirstin. A Passage to Anthropology: Between Experience and Theory. London and New York: Routledge, 1995.

LIMA CAMPO, César Câmara de. A capoeira. Revista Kosmos, Rio de Janeiro, 1906.

Recebido em: 06/08/2010

Aceite em: 10/09/2010 